\title{
Farklı Besin Tiplerinin Ephestia kuehniella Zeller (Lepidoptera: Pyralidae)'nın Total Lipit ve Total Yağ Asidi Yüzdelerine Etkileri
}

\author{
Evrim SÖNMEZ ${ }^{* 1}$, Özgür ÖZCAN², Yeşim KOÇ${ }^{1}$ \\ ${ }^{I}$ Sinop Üniversitesi, Eğitim Fakültesi, Matematik ve Fen Bilimleri Eğitimi Bölümü- Sinop \\ ${ }^{2}$ SASKİ Genel Müdürlüğ̈̈, Su Arıtma Dairesi Başkanlığı, Selahattin Ereren İçme Suyu Arıtma Tesisi, \\ Aşağı Çinik Beldesi- SAMSUN
}

\begin{abstract}
Öz
Denemelerde değirmen güvesi Ephestia kuehniella kullanıldı. Denemeler $28^{\circ} \mathrm{C}, 65 \pm 5$ sıcaklık ve nem şartlarında ve devamlı karanlık koşullarda yapıldı. Besin olarak buğday unu, mısır unu, rüşeym katkılı un ve rüşeym kullanıldı. Belirtilen besinlerde yetiştirilen larva, pup ve ergin dişi ile erkeklerden 3'er tekrar olmak üzere 40 birey alındı. Toplamda her bir deneme için 120 birey kullanıldı. Toplam lipit ve toplam yağ asitlerinin özütlenmesinde Folch vd. [8]'nin geliştirdikleri yöntem uygulandı. Denemeler sonucunda en ağır larva mısır ununda, pup rüşeym katkılı unda, dişi buğday ununda, erkek ise rüşeymde yetiştirilenlerde bulundu. Total lipit larvada en fazla buğday ununda, pup, dişi ve erkekte misır ununda yetiştirilenlerde tespit edildi. Total yağ asidi ise larva ve pupta en fazla mısır ununda, dişi ve erkekte ise rüşeym katkılı unda yetiştirilenlerde bulundu. Değerler arasındaki farklar genellikle istatistiksel olarak anlamlı değildi.
\end{abstract}

Anahtar kelimeler: Ephestia kuehniella, mısır unu, rüşeym, total yağ asidi, total lipit.

\section{The Effects of Different Nutrients on Ephestia kuehniella Zeller (Leipdoptera: Pyralidae)'s Total Lipid and Total Fatty Acid Percentages}

\begin{abstract}
Mill moth E. kuehniella was used in trials. The trials were conducted under continuous dark with a temperature of $28^{\circ} \mathrm{C}$ and $65 \pm 5$ temperature and humidity conditions. Wheat flour, corn flour, wheat germ added wheat flour and wheat germ were used as nutrient. In each trail, 40 individuals and 3 different repeated measurements were made and the analyses. Totaly 120 individuals were used for the trials. Folch et al. [8] method was used to find out the total lipid and total acid percentages of the samples. As a result of the experiments, the heaviest larvae was found in corn flour. Pup was found in wheat germ added wheat flour. Female was found in wheat flour. Male was found in wheat germ. In larval stage, the highest total lipid percentage was found in larvae reared in wheat flour. In pupal period was found corn flour in females and males. In larval and pupal stage, the highest total fatty acid percentage were found in corn flour. Female and male were found in wheat germ added flour. Differences between findings were generally statistically different.
\end{abstract}

Keywords: Ephestia kuehniella, cornflour, wheatgerm, total fatty acid, total lipid.

\section{Giriş}

Ephestia kuehniella depolanmış buğdayın zararlısı olarak da bilinir ve halk arasındaki adı değirmen güvesidir. Depolanmış unlarda ürün kalitesini önemli derecede bozar. E. kuehniella ayrıca tahıl, kepek, ekmek, iç badem, yer fistığı, kuru meyve, bisküvi ve palamut meyvelerinde de zararlıdır [1]. Bu böcekle ilgili biyolojik mücadele çalışmalarında biyolojisinin iyi bilinmesi ve çok iyi çalışılmış olması gerekmektedir. Zararlının gelişmesinde ve hayatta kalmasında besin çeşidi çok önemli olan faktörlerden

\footnotetext{
*Sorumlu yazar: esonmez@ sinop.edu.tr

Geliş Tarihi: 26.09.2018, Kabul Tarihi: 29.01.2019
} 
birisidir. Böceklerde besin, gelişim hızı, farklı gelişim evrelerinin ve erginlerin ağırlığı, verim ve ömür uzunluğu gibi birçok faaliyeti etkiler. Örneğin Callosobruchus maculatus (Coleoptera: Bruchidae) ile yapılan çalışmada düşük kaliteli besinlerle beslenen larvaların, yüksek kaliteli besinlerle beslenen larvalara göre erginleştikleri zaman daha küçük yumurtalar bıraktıkları ve daha kısa ömür uzunluklarına sahip oldukları tespit edilmiştir [2]. Hayvanlardaki yağ asitleri türe, gelişim evresine, çevresel şartlara, beslenme durumuna ve üreme aktivitesine bağlı olarak miktar ve çeşit bakımından değişebilmektedir. C. maculatus'un uçabilen formunun normal formdan yaklaşık iki kat fazla total lipit içerdiği, uçma sırasında lipit miktarının arttığı ve yağ asidi çeşitlerinin her iki eşeyde benzer olduğu tespit edilmiştir [3]. Taşkın [4] Galleria mellonella ile yaptığ 1 ve 5 farklı besin kullandığı bir çalışmada, toplam lipit ve yağ asidi yüzdesinin gliserinli mısır unu ile beslenen grupta diğer gruptakilere göre daha yüksek olduğunu bulmuştur. Aktümsek vd. [5] yine G. mellonella'nın larva ve pupunun yağ asidi bileşimini inceledikleri bir çalışmada doymuş yağ asitleri yüzdesi ve doymamış yağ asitleri yüzdesinin pup evresinde larval evrelere göre daha yüksek olduğunu bulmuşlardır. Nurullahoğlu [6] Achroia grisella ile yaptı̆̆ doymamış yağ asitleri yüzdesinin ise pup evresinde larval evredekine oranla daha yüksek olduğunu bulmuştur. Evans [7], Tenebrio molitor'da metamorfoz süresince toplam karbohidrat miktarının düzenli olarak azaldığını, lipit ve yağ asidi miktarının ise metamorfozun başlangıcındaki miktarlarına göre çok az değişiklik gösterdiğini saptamıştır.

Literatürde E. kuehniella'nın yağ asidi içeriği ile ilgili çalışmalara rastlanmış fakat buğday unu, mısır unu, rüşeym katkılı un ve rüşeymin besin olarak verildiği bir çalışmaya rastlanmamıştır. Bu çalışmadaki amaç farklı besinlerle beslenen, farklı gelişim evrelerindeki E. kuehniella'nın toplam lipit ve yağ asidi yüzdelerini araştırmaktır.

\section{Materyal ve Metot}

\subsection{Deney Gruplarının Oluşturulması}

Denemelerin çekirdeğini Ondokuz Mayıs Üniversitesi Biyoloji Bölümü laboratuvarında bulunan ve en az beş jenerasyon yetiştirilmiş olan $E$. kuehniella oluşturdu. Denemeler $28^{\circ} \mathrm{C}, 65 \pm 5$ sicaklık ve nem şartlarında ve devamlı karanlık koşullarda yapıldı. Denemelere buğday unu (300 mg), mısır unu (300 mg), rüşeym katkılı un (300 mg) ve rüşeym (300 mg) unlarının 500 cc'lik kavanozlara konması ile başlandı. Kavanozlara 10 dişi 10 erkek ergin konuldu ve erginler ölünceye kadar kavanozlar bahsedilen laboratuvar şartlarında bekletildi. Bırakılan yumurtalar larva olmaya başladıktan sonra son evre larvalarından 3 deneme olacak şekilde 40 'ar tane larva alındı ve direkt olarak $-80{ }^{\circ} \mathrm{C}$ 'de analizler yapılıncaya kadar bekletildi. Aynı şekilde $40^{\prime}$ ar tane larva daha alındı ve ayrı petri kaplarına $(9 \times 3 \mathrm{~cm})$ yerleştirildi ve pup olması beklendi. Dişi ve erkek erginler için de aynı süreç takip edildi. İstenilen evreye gelen denemelerin hepsi analizler yapılıncaya kadar $-80^{\circ} \mathrm{C}$ derin dondurucuda (Profilo, 1060) bekletildi.

\section{2. Örneklerin Özütlenmesi}

Her bir deneme için larva, pup, ergin erkek ve dişilerin yaş ağırlıkları alındı. Buğday unu, mısır unu, rüşeym katkılı un ve rüşeymde yetişmiş olan larva, pup ve ergin dişi ile erkeklerden 3'er tekrar olmak üzere 40 birey alındı. Total lipit için 40'ar tane birey, içinde $5 \mathrm{ml}$ kloroform-metanol $(2: 1 ; \mathrm{v} / \mathrm{v})$ çözeltinin bulunduğu tüplerde homojenizatörde (Pro 200) 35.000 r.p.m., 5 dakika homojenize edildi. Homojenat filtre kâğıdında (Whatman No: 40) süzüldü ve çözücü $\mathrm{N}_{2}$ gazı altında uçuruldu. Sabit tartıma gelinceye kadar desikatörde (Silica jel ile) bekletildi. Bulunan değerler birey sayısına bölünerek birey başına düşen ağırlıklar saptandı. Toplam lipit ve toplam yağ asitlerinin özütlenmesinde Folch ve vd. [8]'nin geliştirdikleri yöntem uygulandı.

\subsection{Verilerin Analizi}

Verilerin istatistiksel analizleri SPSS for Windows (ver.21) software paket programı kullanılarak yapıldı. Grupların karşılaştırılmasında nonparametrik analiz Kruskal-Wallis H testi kullanıldı. Bu testten 
elde edilen sonuçların önemli olması durumunda ortalamalar "Mann-Whitney U Testi" kullanılarak değerlendirildi. Sonuçların değerlendirilmesinde $\alpha=0.05$ güven sınırı esas alındı.

\section{Bulgular ve Tartışma}

Farklı besin tiplerinin E. kuehniella'nın larva, pup, dişi ve erkek ağırlıklarına etkisi Tablo 1 ve Şekil 1 'de verildi. Tablo 1'den de görüleceği gibi en ağır larva mısır ununda yetiştirilenlerde, en ağır pup rüşeym katkılı unda yetiştirilenlerde, en ağır dişi buğday ununda yetiştirilenlerde ve en ağır erkek ise rüşeymde yetiştirilenlerde bulundu. Pup evresinde yaş ağırlık besin tipine göre değişim göstermezken, larva ve ergin dönemde besin tipinin etkisinin anlamlı olduğu tespit edildi (Man-Whitney $U, p \leq 0.05$ ). Şekil 1'e bakıldığında her bir besin grubunda en ağır safhanın larva safhası olduğu, sadece rüşeym ile beslenen grupta larva ve pup arasında ağırlık farkının önemsiz olduğu görüldü. Dişi ve erkek ağırlıkları karşılaştırıldığında ise buğday unu, mısır unu ve rüşeym katkılı unda yetiştirilenler arasındaki değerler istatistiksel olarak anlamlıydı (Şekil 1) $(\mathrm{p} \leq 0.05)$.

Tablo 1. E. kuehniella'nın larva, pup, dişi ve erkek yaş ağırlıklarına besin tipinin etkisi

\begin{tabular}{lllll}
\hline \multicolumn{5}{c}{${ }^{\mathbf{1}}$ Ortalama \pm S.D. (mg) } \\
\hline Besin Tipi & Larva & Pup & Dişi & Erkek \\
\hline Buğday Unu & $6.57 \pm 0.32 \mathbf{a}$ & $4.27 \pm 0.01 \mathbf{a}$ & $4.41 \pm 0.05 \mathbf{a}$ & $3.00 \pm 0.15 \mathbf{a}$ \\
Misır Unu & $7.53 \pm 0.31 \mathbf{b}$ & $4.27 \pm 0.01 \mathbf{a}$ & $3.99 \pm 0.02 \mathbf{b}$ & $2.94 \pm 0.18 \mathbf{a}$ \\
Ruşeym Katkı1ı Un & $6.16 \pm 0.20 \mathbf{c}$ & $4.47 \pm 0.39 \mathbf{a}$ & $3.04 \pm 0.54 \mathbf{c}$ & $2.77 \pm 0.95 \mathbf{a b}$ \\
Ruşeym & $3.89 \pm 0.69 \mathbf{d}$ & $4.27 \pm 0.14 \mathbf{a}$ & $2.74 \pm 0.01 \mathbf{c}$ & $3.52 \pm 0.15 \mathbf{b}$
\end{tabular}

${ }^{1}$ Her bir denemede 40 birey kullanılan 3 tekrarın ortalamasıdır.

Aynı sütunda aynı küçük harfle gösterilmiş değerler arasındaki fark istatistiksel olarak önemsizdir $(p>0.05)$

S. D.: Standart Sapma

mg: miligram

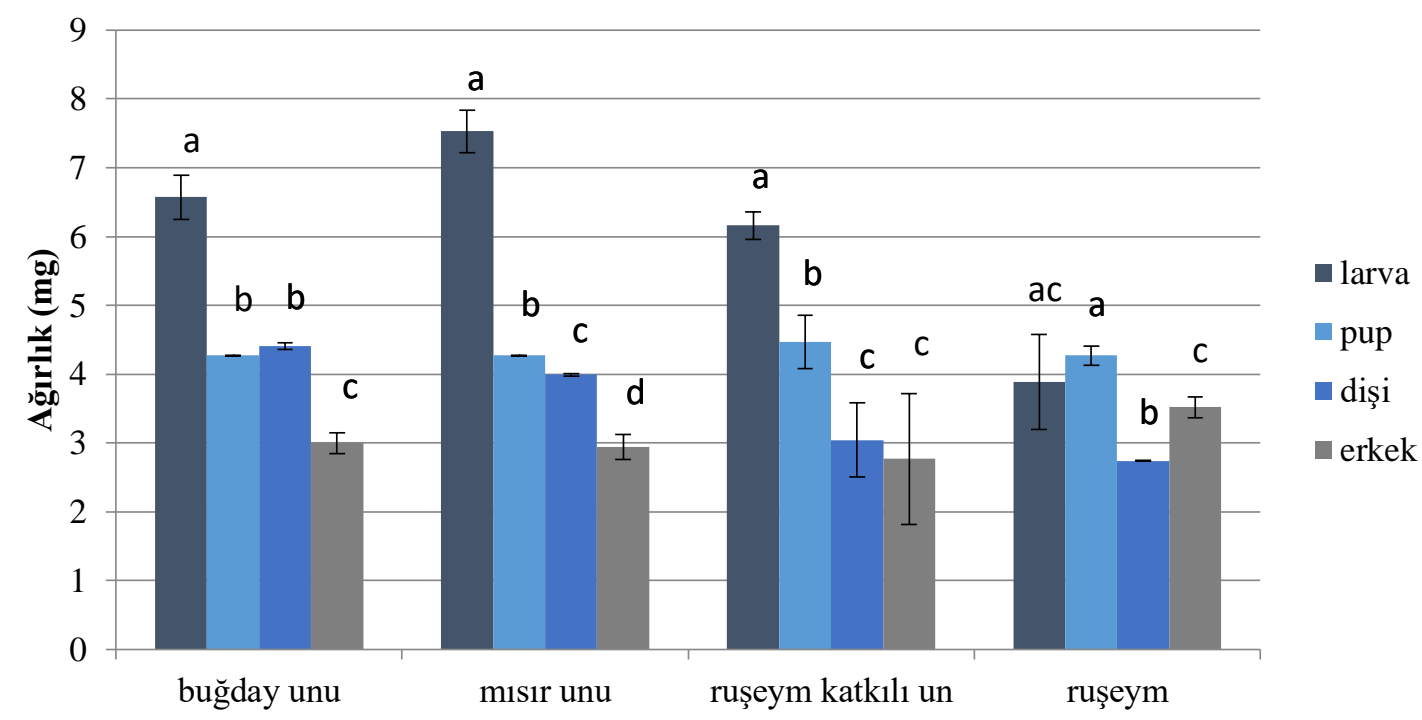

Şekil 1. Farklı besin tiplerinin E. kuehniella'nın larva, pup, dişi ve erkek ağırlıklarına (mg) etkisi (gelişim evreleri her bir besin türü için ayrı ayrı karşılaştırılmıştır)

Farklı besin tiplerinin E. kuehniella'nın larva, pup, dişi ve erkeklerin total lipit yüzdesine etkisi Tablo 2 ve Şekil 2'de verildi. Tablo 2'den de görüldügü gibi larval evrede en fazla total lipit yüzdesi buğday ununda yetiştirilenlerde, pup evresinde ise dişi ve erkekte misır ununda yetiştirilenlerde elde edildi. Şekil 2'ye bakıldığında her bir besin grubunda, larva safhasının diğer gelişim safhalarından daha 
yüksek miktarda lipit içerdiği gözlendi. Dişi ve erkekler arasında ise sadece rüşeym katkılı unda yetiştirilmiş olanlar arasındaki fark istatistiksel olarak anlamlıydı (Şekil 2) $(\mathrm{p} \leq 0.05)$.

Tablo 2. E. kuehniella'nın larva, pup, dişi ve erkeklerin total lipit (\%) yüzdelerine besin tipinin etkisi

\section{${ }^{1}$ Ortalama \pm S.D.}

\begin{tabular}{lllll}
\hline Besin Tipi & Larva & Pup & Dişi & Erkek \\
\hline Buğday Unu & $0.69 \pm 0.09 \mathbf{a b}$ & $0.30 \pm 0.02 \mathbf{a}$ & $0.22 \pm 0.02 \mathbf{a}$ & $0.19 \pm 0.03 \mathbf{a}$ \\
Misır Unu & $0.68 \pm 0.02 \mathbf{a}$ & $0.49 \pm 0.01 \mathbf{b}$ & $0.34 \pm 0.03 \mathbf{b}$ & $0.38 \pm 0.17 \mathbf{b}$ \\
Ruşeym Katkılı Un & $0.59 \pm 0.01 \mathbf{b}$ & $0.15 \pm 0.01 \mathbf{c}$ & $0.12 \pm 0.03 \mathbf{c}$ & $0.36 \pm 0.25 \mathbf{a b}$ \\
Ruşeym & $0.44 \pm 0.14 \mathbf{c}$ & $0.15 \pm 0.04 \mathbf{c}$ & $0.26 \pm 0.11 \mathbf{b}$ & $0.18 \pm 0.08 \mathbf{a b}$ \\
\hline
\end{tabular}

Tablo açıklamaları Tablo 1'deki gibidir.

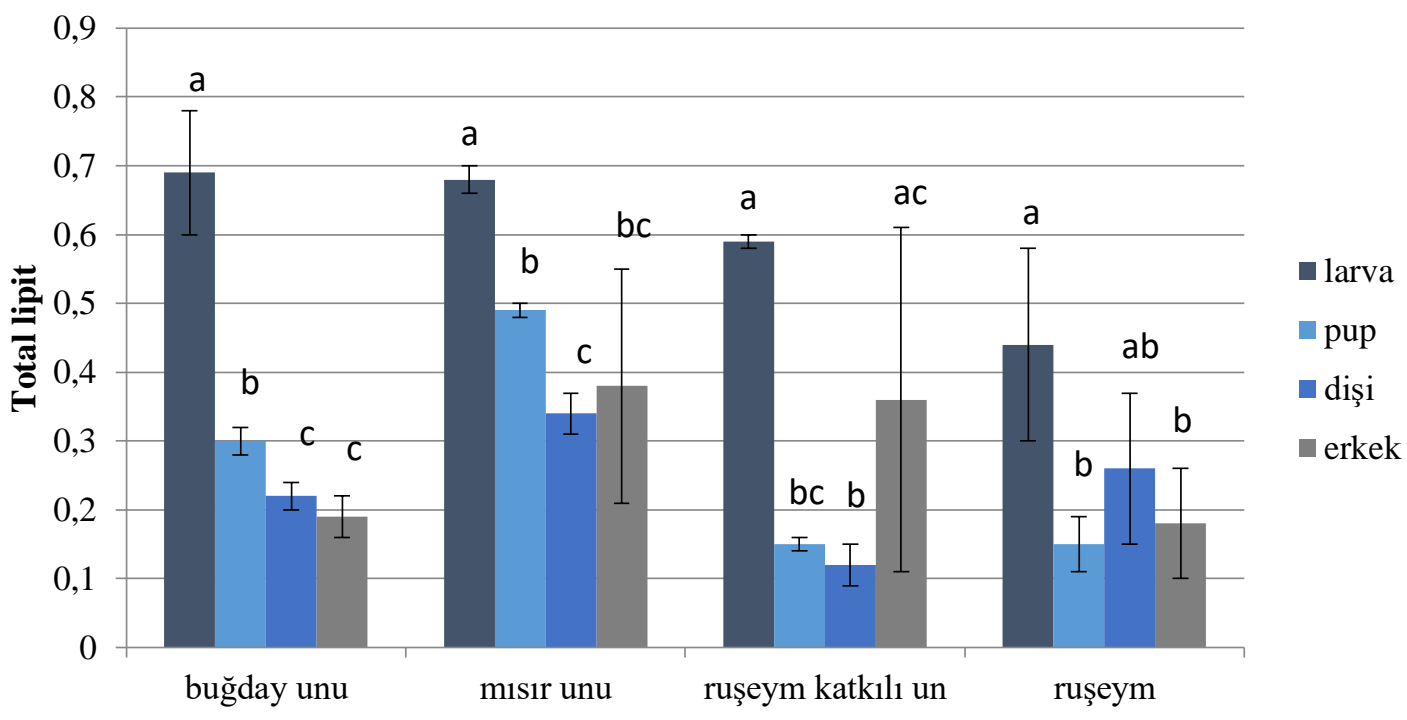

Şekil 2. Farklı besin tiplerinin E. kuehniella'nın larva, pup, dişi ve erkeklerin total lipit (\%) yüzdelerine etkisi

Farklı besin tiplerinin E. kuehniella'nın larva, pup, dişi ve erkeklerin total yağ asidi yüzdesine etkisi Tablo 3 ve Şekil 3'de verildi. Verilere göre en fazla total yă asidi yüzdesi larva ve pupta mısır ununda yetiştirilenlerde, dişi ve erkekte ise rüşeym katkılı unda yetiştirilenlerde elde edildi. Şekil 3'de görüldüğ̈ gibi besin tipine göre gelişim safhaları karşılaştırıldığında, rüşeym katkılı un ve rüşeym ile beslenen grupta en fazla yağ asidi içeren grubun ergin dişi olduğu belirlendi. Genel olarak bakıldığında gelişim safhaları arasındaki total yağ asidi yüzdesinin çok büyük bir değişim göstermediği tespit edildi. Dişi ve erkeler karşılaştırıldığında ise buğday unu ve rüşeymde yetiştirilmiş olanlardaki farklar istatistiksel olarak anlamlıydı (Şekil 3) $(\mathrm{p} \leq 0.05)$.

Tablo 3. E. kuehniella'nın larva, pup, dişi ve erkeklerin total yağ asidi (\%) yüzdelerine besin tipinin etkisi

${ }^{1}$ Ortalama \pm S.D.

\begin{tabular}{lllll}
\hline Total Yağ Asidi & Larva & Pup & Dişi & Erkek \\
\hline Buğday Unu & $0.057 \pm 0.009 \mathbf{a}$ & $0.073 \pm 0.001 \mathbf{a}$ & $0.048 \pm 0.017 \mathbf{a}$ & $0.073 \pm 0.004 \mathbf{a}$ \\
Misır Unu & $0.085 \pm 0.026 \mathbf{a}$ & $0.111 \pm 0.045 \mathbf{b c}$ & $0.064 \pm 0.014 \mathbf{a c}$ & $0.067 \pm 0.018 \mathbf{a}$ \\
Ruşeym Katkılı Un & $0.071 \pm 0.014 \mathbf{a}$ & $0.092 \pm 0.008 \mathbf{c}$ & $0.141 \pm 0.109 \mathbf{b}$ & $0.082 \pm 0.035 \mathbf{a}$ \\
Ruşeym & $0.058 \pm 0.009 \mathbf{a}$ & $0.058 \pm 0.019 \mathbf{a b}$ & $0.109 \pm 0.040 \mathbf{b c}$ & $0.037 \pm 0.010 \mathbf{b}$ \\
\hline
\end{tabular}

Tablo açıklamaları Tablo 1'deki gibidir. 


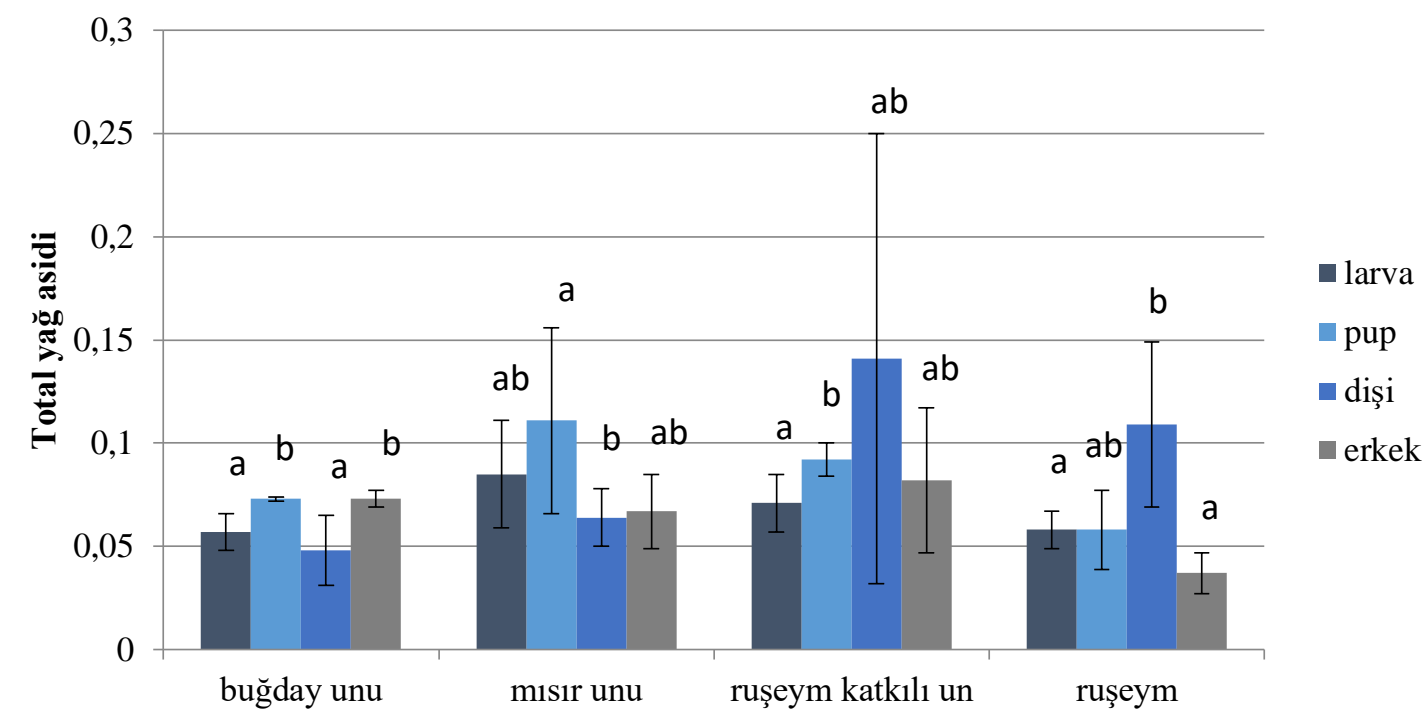

Şekil 3. Farklı besin tiplerinin E. kuehniella'nın larva, pup, dişi ve erkeklerin total yağ asidi (\%) yüzdelerine etkisi

Besinin ergin öncesi gelişime, ağırlığa, karbonhidrat, glikojen, protein, amino asit, total lipit, total yağ asidi ve yağ asidi çeşitlerine etkisi ile ilgili birçok araştırma mevcuttur. E.kuehniella ile yapılan bir çalışmada hemolenf lipitlerinin prepupal evrede oldukça yüksek olduğu görülmüşken, erken larval evrede ise oldukça düşük olduğu bulunmuştur [9]. Bir böceğin sahip olduğu lipit ve yağ asidi miktarı böceğin ergin öncesi gelişim evresine, ergin döneminde üreme açısından aktif olup olmamasına ve yaşına bağlıdır. Aksoy vd. [10] Sesamia nonagrioides ile yaptıkları bir çalışmada larva döneminde vücut yapısında biriken karbohidrat, protein ve lipit miktarının daha sonraki dönemlerde değiştiğini; pupalarda azaldığını, ergin evrede ise arttığını belirlemişlerdir.

Bombyx mori [11] ile yapılan bir çalışmada larva, pupa ve erginlerinin total yağ asidi yüzdelerinde birinci larval evreden itibaren artış görülmüş ve ergin dönemin en fazla total yağ asidi yüzdesine sahip olduğu tespit edilmiştir. Subramanyam ve Cutkompl [12] yine $P$. intepunctella ile yaptıkları bir çalışmada ise son larval evrede erkeklerin çok fazla miktarlarda total lipit içerdiğini tespit etmişlerdir. Kalyoncu ve Özge [13] P. interpunctella larva, pup ve erginlerinin yağ asidi bileşimlerini incelemişlerdir. Yağ asidi yüzdelerinde gelişim evrelerine göre farklılıklar belirlenmiştir. Doymuş yağ asidi yüzdesi larval evrede en yüksek iken, aşırı doymamış yağ asidi yüzdesi ise pup evresinde en yüksek olarak tespit edilmiştir.

Çalışmamızda en ağır larva mısır ununda, pup rüşeym katkılı unda, en ağır dişi buğday ununda, en ağır erkek ise rüş̧eymde yetiştirilenlerde bulundu. Mısır ununda karbohidrat oranı çok yüksek ve protein oranının ise çok düşük olmasından dolayı en ağır larva mısır ununda tespit edilmiş olabilir. En fazla total lipit içeriği pup, dişi ve erkekte mısır ununda tespit edildi. En fazla total yağ asidi içeriği ise larva ve pupta mısır ununda, dişi ve erkekte ise rüşeym katkılı unda yetiştirilenlerde tespit edildi. Holometabol böceklerde özellikle ergin öncesi evrelerde kullanılan besin tipi, gelişim süresinde, metamorfozda ve ergin evrede etkili olur. Çalışmamızda özellikle larva ve pup aşamalarında genellikle en ağır ve en yüksek total lipit ile total yağ asidinin mısır ununda çıkması bu böceğin ergin öncesi gelişim aşamalarında, metamorfoz sırasında çok yüksek miktarlarda karbohidrat ihtiyacının olmasından ve bunu da mısır unundan karşılamasından kaynaklanabilir. Özellikle tüm evrelerde total lipit miktarı larva grubu hariç en fazla mısır ununda yetiştirilenlerde bulundu ve elde edilen değerler arasındaki farklar istatistiksel olarak anlamliyd1.

Genel olarak bakıldığında çalışmamızda en az total lipit içeriği rüşeym ve buğday ununda yetiştirilenlerde bulunmuşken, en fazla yağ asidi içeriği rüşeym katkılı unda bulunmuştur. Rüşeymin yüksek miktarlarda karbonhidrat, protein ve yağ asidi içeriğine sahip olduğu bilinmektedir.

Böcek gelişimi ve fizyolojisiyle ilgili araştırmalarda besin türünün metabolik aktiviteyi değiştirerek gelişim hızını etkilediği ve buna bağlı olarak fekundite, ömür uzunluğu, içerdiği madde miktarı gibi birçok faaliyeti değiştirebildiği tespit edilmiştir [14]. Üstüner vd. [15] P. interpuctella ile yaptıkları bir çalışmada böceği farklı besinlerde yetiştirmişler (fındık, yerfistığı, ceviz, badem ve polen), besin çeşidine göre larvalarda total yă̆ asidi ve total lipit yüzdelerinde farkl1lıklar tespit etmişlerdir. 
Taşkın ve Aksoylar [16] Itoplectis melanocephala ile yaptıkları bir çalışmada total lipit ve total yağ asidi yüzdelerinin ergin öncesi dönemde oldukça fazla olduğunu, bu değerin ergin oldukları döneme doğru ise azaldığını tespit etmişlerdir. Bu durum ergin dönemde gerçekleşen üreme faaliyetlerinden dolayı böceklerin ihtiyacının değişmesi, dişilerde yumurta üretiminde, erkeklerde üreme için enerji gereksiniminin karşılanmasında total lipit ve yağ asitlerinin tercih sebebi olmasından da kaynaklanabilir.

\section{Sonuç ve Öneriler}

Besin içerisindeki bileşenler bazen böceklerin yağ asidi kompozisyonunu da etkiler. Böcekler metabolik ihtiyaçları için gerekli olan yağların bir kısmını besinde bulunan karbohidratlardan sentezleyerek karşılarlar. Böcekler ergin öncesi gelişim aşamalarında besin depolayabilirler ve ergin öncesi evredeki besinler oldukça önemlidir [17, 18].

Sonuç olarak buğday unu, mısır unu, rüşeym katk1lı un ve rüşeym ile beslenen E. kuehniella'nın yaş ağırlığı, total lipit ve total yağ asidi miktarları arasında farklılıklar bulundu. Bu farklılıklar böceğin gelişim evrelerine, dişi veya erkek olup olmamasına ve bu evrelerdeki metabolik ihtiyaçlarına göre değişebilir. Çalışmamız sonucunda mısır ununda yetiştirilen larva ve pup gibi gelişim aşamalarında total lipit ve total yăg asidi oranının yüksek çıkmasından dolayı, konak parazitoit ilişkilerini ele alan fizyolojik çalışmalarda mısır unu katkılı besinlerde yetiştirilmesi tavsiye edilir. Bunun yanında erginlerde total yağ asidi yüzdesinin rüşeym katkılı unda fazla çıkması nedeniyle yapılacak fizyolojik çalışmalarda rüşeym katkılı unda alternatif olabilir.

\section{Kaynaklar}

[1] Erakay S. 1974. Ege Bölgesinde Un ve Undan Mamül Maddelerde Bulunan Zararlı Böcekler Üzerinde Araştırmalar. İstiklal Matbaası, İzmir, Teknik bülten, 23: 34-35.

[2] Gonzalaez-Teuber M., Segovia R., Gianoli E. 2008. Effects of Maternal Diet and Host Quality on Oviposition Patterns and Offspring Performance in a Seed Beetle (Coleoptera: Bruchidae). Naturwissenschaften, 95 (7): 609-615.

[3] Nwanze K.F., Maskarinec J.K., Hopkins T.L. 1976. Lipid Composition of the Normal and Fligth Forms of Adult Cowpea Weevils, Callosobruchus maculatus. Journal of Insect Physiology, 22 (6): 897-899.

[4] Taşkın D. 2010. Besinin Galleria mellonella (L.) (Lepidoptera: Pyralidae) Puplarının Toplam Lipit ve Toplam Yağ Asidi Yüzdelerine Etkisi. Balıkesir Üniversitesi Fen Bilimleri Enstitüsü Dergisi, 12 (2): 50-54.

[5] Aktümsek A., Nurullahoğlu Z.Ü., Kalyoncu L. 2000. Galleria mellonella (L.) (Lepidoptera: Pyralidae) Larva ve Pupunun Yağ Asidi Bileşimi. Selçuk Üniversitesi Fen-Edebiyat Fakültesi Fen Dergisi, 17: 29-32.

[6] Nurullahoğlu Z.Ü. 2003. Achroia grisella (Lepidoptera: Pyralidae) Larva ve Pupunun Yăg Asidi Bileşimi. S.Ü. Fen-Edebiyat Fakültesi Fen Dergisi, 21: 75-78.

[7] Evans A.C. 1934. On the Chemical Changes Associated with Metamorphosis in a Beetle (Tenebriomolitor L.). Journal of Experimental Biology, 11: 397-401.

[8] Folch J., Lees M., Stanley S.G.H. 1956. A Simple Method for the Isolation and Purification of Total Lipids from Animal Tissues. The Journal of Biological Chemistry, 2261: 497-509.

[9] Gussin A.E.S. 1967. Lipid Metabolism in the Mediterranean Meal Moth Ephestia kuhniella Zeller During Its Life Cycle. Indiana Academy of Science, 311-318

[10] Aksoy H.A., Bahadıroğlu C., Toroğlu S. 2015. Mısır Koçan Kurdu, Sesamia nonagrioides Lefebvre (Lepidoptera: Noctuidae)'in Farklı Gelişme Evrelerinde Toplam Protein, Karbohidrat ve Lipit Miktarı Üzerine Araştırma. Düzce Üniversitesi Bilim ve Teknoloji Dergisi, 3: 125-131.

[11] Nakasone S., Ito T. 1967. Fatty Acid Composition of the Silkworm, Bombyx mori L. Journal of Insect Physiology, 13: 1237-1246.

[12] Subramanyam B., Cutkompl L.K. 1987. Total Lipid and Fatty Acid Composition in Male and Female Larvae of Indian-Meal Moth and Almond Moth (Lepidoptera: Pyralidae). The Great Lakes Entomologist, 20 (2): 99-102.

[13] Kalyoncu L., Özge S. 2014. Plodia interpunctella (Hubner) (Lepidoptera: Pyralidae)'nın Farklı Gelişim Evrelerinin Yağ Asidi Bileşimi. Selçuk Üniversitesi Fen Fakültesi Fen Dergisi, 38: 10-18. 
[14] El Atta H.A. 2000. Effect of Diet and Seed Pretreatment on the Biology of Bruchidius uberatus (Coleoptera: Bruchidae). Silva Fennica 34 (4): 431-435.

[15] Üstüner P., Kalyoncu L., Aktümsek A. 2010. Besinin Plodia interpunctella (Hubner) (Lepidoptera: Pyralidae) Larva ve Pupunun Toplam Lipid, Yağ Asidi Oranlarına ve Yağ Asidi Bileşimine Etkileri. Süleyman Demirel Üniversitesi Fen Dergisi (E-Dergi), 5 (1): 29-37.

[16] Taşkın D., Aksoylar M.Y. 2011. Itoplectis melanocephala (Gravenhorst, 1829) (Hymenoptera: Ichneumonidae)'nın Ergin Öncesi Dönemleri ile Erginlerinin Total Lipid ve Total Yăg Asidi Yüzdeleri. Türkiye Entomoloji Dergisi, 35 (4): 641-649.

[17] Perez-Mendoza J., Hagstrum D.W., Dover B.A., Hopkins T.L., Baker J.E. 1999. Fligth Response, Body Weigth and Lipid Content of Rhyzopertha dominica (F) Coleoptera: Bostrichidae) as Influenced by Strain, Season and Phenotype. Journal of Stored Products Research, 35: 183-196.

[18] Guerra A.A., Robacker D.C. 1989. Effects of Sex, Age and Diet on the Triacylglcerol Fatty Acid Composition of Subtropical Boll Weevils, Anthonomus grandis Boheman (Coleoptera: Curculionidae). Journal of Agricultural Food and Chemistry, 37: 796-799 